\title{
The Bacterial Flora on Selected Organs of Oreochromis Niloticus in Lake Chivero, Zimbabwe
}

\author{
Innocent Hove ${ }^{1 *}$, Claudious Gufe2, Maxwel Barson11, Sitokozile Sibanda2, Pious Vengesai Makaya² \\ 1Department of Biological Sciences, Faculty of Science, University of Zimbabwe, P.O. Box MP167 Mt Pleasant, Harare, Zimbabwe \\ 2Department of Veterinary Services, Diagnostics and Research Branch, Central Veterinary Laboratories, P. O. Box CY551, Harare, \\ Zimbabwe
}

\section{*Corresponding Author}

Innocent Hove

\section{Article History}

Received: 22.10.2019

Accepted: 01.11.2019

Published: 04.11.2019

\begin{abstract}
Fish can harbour and spread pathogenic bacteria that form the natural micro-flora of the environment, but the flora may be altered by man's activities such as sewage effluent disposal. The aim of this study was to isolate, identify and enumerate bacteria associated with the different organs of Oreochromis niloticus in Lake Chivero, Zimbabwe and compare their diversity and prevalence. Bacteria were isolated, identified and enumerated from the gills, intestine, kidney, liver, muscle and skin of thirty (30) fish using the culture-based technique on selective and non-selective media. A total of twelve (12) bacteria were isolated, namely Acinetobacter spp., Aeromonas spp., Bacillus subtilis, Citrobacter spp., Edwardsiella tarda, Enterobacter spp., Escherichia coli including E. coll 0157:H7, Klebsiella spp., Listeria ivanovii, Shigella spp., Staphylococcus spp., and an unidentified isolate. Staphylococcus spp. were most prevalent on primarily all organs with prevalence rates ranging from $53.3 \%$ to $100 \%$. Escherichia coli 0157:H7 was least prevalent and was not detected on intestine, liver and kidney. Staphylococcus spp. was the most abundant isolate $\left(1.46 \times 10^{5} \pm 4.014\right.$ $\times 10^{4} \mathrm{cfu} / \mathrm{g}$ ) on the skin whereas E. coli, L. ivanovii and Shigella spp. were absent on the kidney. Fish pathogenic bacteria (Aeromonas spp. and Edwardsiella tarda) did not vary significantly in their distribution between the organs $(p>0.05)$, though high counts were recorded on the gills. Opportunistic pathogens of fish and humans, were significantly high on external organs mainly the skin and gills. The high bacterial infection levels indicate that the fish are heavily stressed and this may negatively impact the populations of 0 . niloticus in Lake Chivero. The several human pathogenic bacteria isolated render 0 . niloticus unfit for consumption according to the CODEX Alimentarius standards and pose health risks to consumers.
\end{abstract}

Keywords: Oreochromis Niloticus Chivero, Bacteria.

\section{INTRODUCTION}

Fish are one of the largest groups in the animal kingdom and they are present in various aquatic environments. These aquatic environments range from freshwater to marine environments and they present several habitats and niches for different fish groups. Also present in these environments are complex groups of protistan and metazoan organisms as well as fungal, bacterial and viral microorganisms that interact with fish as symbionts, commensals, parasites or pathogens [1]. Some of the organisms have been shown to be beneficial offering movement, digestion, eicosapentaenoic acid production, neuramindase and histamine production [2] Microorganisms mainly bacteria play a role in the production of vitamin B 12 in the intestine of carp [3].

Freshwaters are the habitat of about $40 \%$ of the fish species [1]. The properties of natural water do not generally support the growth of microorganisms as they are void of habitats such as soil, plants or animals which are mainly natural habitats of microorganisms. Natural waters are oligotrophic and resident aquatic microorganisms are adapted to these conditions through biofilm formation. Microbes mainly occupy two main habitats in water: the air-water interphase while others sediment. Typical freshwaters were initially thought to be dominated by coliforms and Proteus bacteria as well as Flavobacterium and Achromobacter spp. [1]. However, molecular techniques mainly $16 \mathrm{~S}$ rRNA sequencing have revealed more phyla of bacteria in water including alpha-, delta-, epsilon- and beta- proteobacteria, Actinobacteria, Cytophaga and cyanobacteria [4]. The significance of the microbial flora in the aquatic environment includes photosynthesis, sulphate reduction and metabolic activity in the nitrogen cycle [5]. Anthropogenic

Copyright @ 2019: This is an open-access article distributed under the terms of the Creative Commons Attribution license which permits unrestricted use, distribution, and reproduction in any medium for non commercial use (NonCommercial, or CC-BY-NC) provided the original author and source are credited. 
activities introduce bacteria that are not natural in aquatic systems such as Pseudomonas, Bacillus, Vibrio and members of the Enterobacterioceae family.

According to Austin [6], the bacterial flora of fish is mainly determined by the water and feed and it comprises gram positive and gram negative bacteria. Also the surface tissues (the skin and gills) usually have a higher bacterial count than the internal organs. The digestive tract comprises a diversity of bacteria that are crucial in nutrition production for the fish. Internal organs such as liver, spleen and kidney are also found to be infected with bacteria even in healthy fish. Tissue such as the muscle is believed to be sterile while eyes of healthy fish are devoid of bacteria.

Studies on fish bacteriology have been carried out mainly focusing on human health implications associated with the fish bacterial flora after harvesting [7, 8]. A significant number of bacteria have been shown to cause disease in fish. Bacteria such as Flexibacter, Flavobacterium, Edwardsiella, Yersinia and Aeromonas spp, Vibrio spp, Mycobacterium spp, some members of the Enterobacteriaceae family such as Proteus spp and Serratia spp, and Pasteurella spp have been isolated from different organs of fish [9]. Bacteria associated with fish can be categorized into three groups: (i) indeginous bacteria (Clostrodium botulinium, pathogenic Vibrio spp. and Aeromonas hydrophilla), (ii) enteric bacteria that are present due to feacal contamination (Salmonella spp., Shigella spp., pathogenic Escherichia coli and Staphylococcus aureus), and (iii) bacteria introduced during processing, storage and preparation for consumption (Bacillus cereus, Listeria monocytogenes, Staphylococcus aureus, Clostridium perfrigens and Salmonella spp.) [10]. The flora of fish is directly related to the health of the fish and also affects other animals in the ecosystem. The bacterial diseases of fish include fin rot, furunclulosis, hemorrhagic ulcers and septicemic disorders, vibriosis, yersiniosis, enteric septicemia, columnaris, mycobacteriosis, bacterial gill disease and bacterial kidney disease $[11,12]$.

Lake Chivero was constructed in 1952 by the impoundment of the Manyame River to supply water to Harare city. City of Harare as well as its satellite townships lies within its own catchment area discharging sewage and industrial effluent into the lake's main tributaries; the Manyame, Marimba and Mukuvisi rivers thus increasing the organic content of the lake. Eutrophication was reported in the lake as early as the 1960's [13]. In Zimbabwe, fish are distributed countrywide in lakes and rivers such as lakes Kariba and Chivero. Lake Chivero is of particular interest because it is located downstream of Harare city effluent outfall and has occasionally received untreated or insufficiently treated sewage and industrial waste [14] and is hypereutrophic [15]. The composition of dissolved nutrients such as dissolved organic nitrogen (DON) and dissolved organic phosphorus (DOP) are very high, reported at 1,840 $\mu \mathrm{g} L$ 1DOP [15]. Eutrophication can occur naturally (rainfall runoff) or can be due to anthropogenic activities (domestic and industrial waste). It drastically increases ammonia concentration leading to bioaccumulation and biomagnification of pathogenic organisms that are otherwise less concentrated in freshwater environments [16, 17] and this increases the prevalence of fish pathogenic and opportunistic bacteria which are usually low in clean aquatic systems.

Lake Chivero is a habitat of several cichlid fish species such as native (Tilapia rendalli, T. sparrmanii and Pseudocrenilabrus philander) and introduced (Oreochromis spp. and Serranochromis robustus) [18]. Several studies addressing water quality and fish parasitology [19] have been done quite extensively in the Manyame system including Lake Chivero. Microcystin levels in the lake were recorded at $19.9 \mathrm{\mu gL}^{-1}$ exceeding the recommended level of $1.0 \mu \mathrm{gL}^{-1}$ [20]. Blue green algae has been correlated to increase fish populations [21], however, massive algal blooms of up to $42.2 \mu \mathrm{gL}^{-1}$ resulted in the fish kills from February 2003 to November 2004 [22]. Human pathogenic bacteria such as E. coli, Vibrio spp., Salmonella spp., Shigella spp., Staphylococcus spp. and faecal Streptococcus were isolated from the lake [23]. Parasites including Ascaris lumbricoides eggs, Entamoeba histolytica, Isospora beli, Taenia spp. and Schistosoma mansoni were reported in the same study. The evidence of the diversity of these microorganisms in the Lake can significantly alter the microflora of fish.

The bacterial flora of fish in such a eutrophic environment was of particular interest in this study. This study was designed to investigate the bacterial flora (whether resident or transient flora) of Oreochromis niloticus in Lake Chivero. Oreochromis niloticus was introduced in the lake in the 1980's [24] and is highly invasive due to its wide range of trophic and ecological adaptations. Oreochromis niloticus is currently the most dominant fish species in the lake and can easily transcend other fish species. It dominates aquaculture worldwide (up to $72 \%$ production annually), is essential for economic development and protein security [25] and is most preferred as food locally [26]. Bacteria such as Streptococcus spp. can lead to high fish mortalities if they infect internal organs such as the kidney $[9,27]$. Furthermore, the fish from such a contaminated environment can be a source of infection to the public who so incessantly eat fish from the lake. The quantitative and qualitative estimation of the bacterial flora of 0 . niloticus was of importance as it ascertained the possible health implications associated with the bacterial diversity of 0 . niloticus on the fish as well as humans. The objectives of this study were to isolate and identify bacteria infecting the different organs of 0 . niloticus in Lake Chivero, to determine the prevalence of the bacterial isolates and compare their diversity and abundance on different organs. We hypothesise that the mean abundances of the bacterial isolates on different fish organs (skin, gills, muscle, intestine, liver and kidney) are the same. 


\section{MATERIALS ANd Methods \\ Study site}

The study area, Lake Chivero is situated $32 \mathrm{~km}$ from Harare capital city; coordinates (-17.872781, 30.797493) (Figure 1). The lake has a shore length of approximately $48 \mathrm{~km}$ and a surface area of $2632 \mathrm{ha}$. The maximum depth is $27 \mathrm{~m}$ and the maximum width is $8 \mathrm{~km}$ with a capacity of $2.5 \times 10^{8} \mathrm{~m}^{3}$ of water [28].

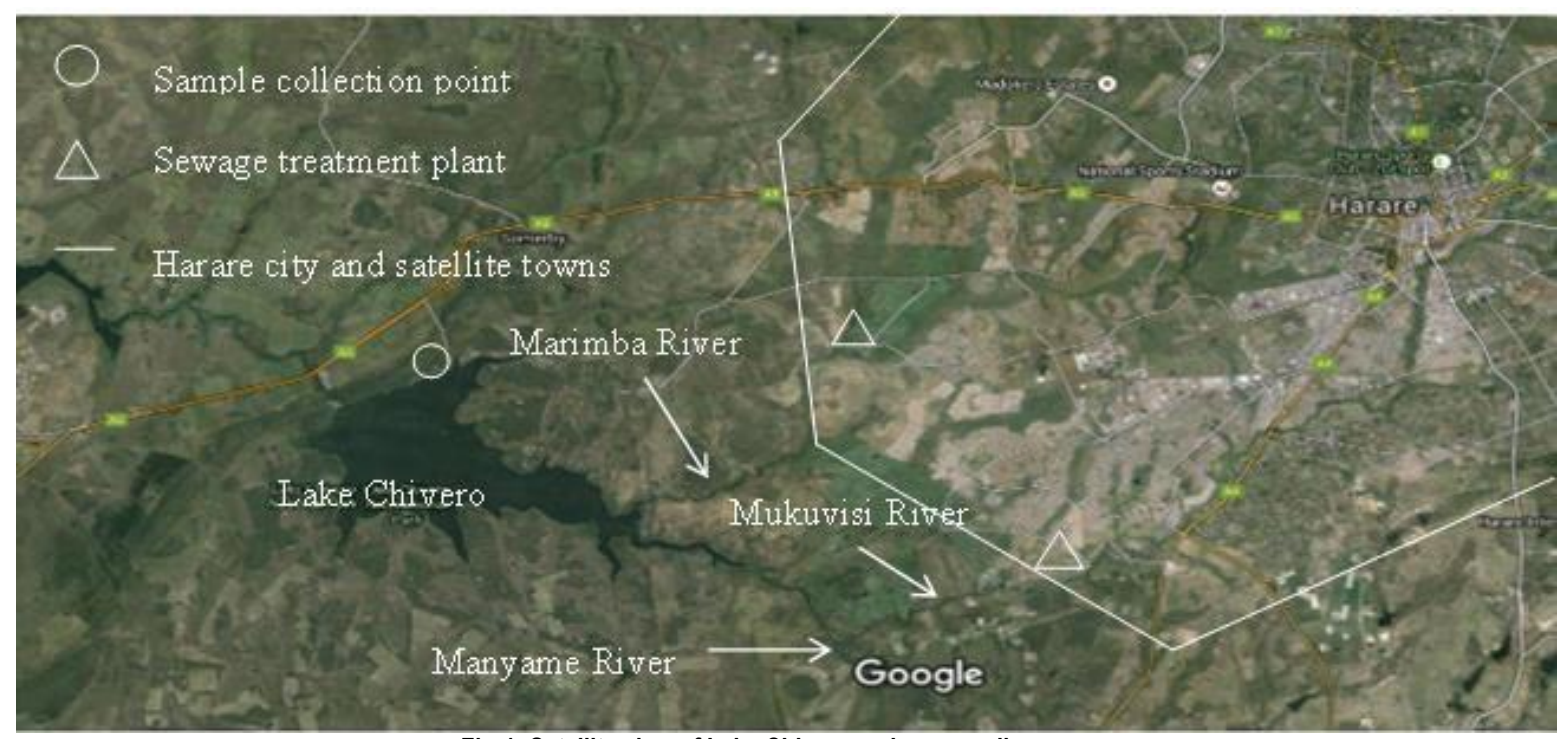

Fig-1: Satellite view of Lake Chivero and surrounding areas

\section{Sample collection and preparation}

A total of thirty (30) fish samples (O. niloticus) were collected in February 2016 at the fisheries at Kamba Caravan Park station situated at Lake Chivero (Figure 1). The fish were caught by the fisheries gill nets set over night on various locations around the lake. Immediately upon arrival of boats on the shore and before handling by vendors, fish samples were randomly selected, placed in sterile zip-lock bags separately, stored on ice and transported to the Central Veterinary Laboratory (Bacteriology section) at Division of Veterinary Services in Harare. Upon arrival at the laboratory, the samples were processed immediately for identification of bacteria.

For each fish sample portions of the skin (including scales and underlying epidermis tissue), gills, muscle, intestines, liver and kidney were aseptically cut and placed in separate universal bottles. The dissection of all samples was sequential; starting by the dissection of the skin followed by the muscle, gills, intestine, liver and finally kidney. One (1) gram portions of the skin (approximately 8 $\mathrm{cm}^{2}$ ), muscle, gills, intestines and liver, and the entire kidney were removed and mixed in phosphate buffered saline (PBS) in a ratio of 1 part sample to 9 parts PBS to make a $10^{-1}$ dilution. The diluted specimens were then homogenized using the IKA® T25 Basic Ultra TURRAX® homogenizer (IKA, China). Serial dilutions were then performed in exponents of ten where needed.

\section{Culture preparation and enumeration of colony forming units}

The homogenate $(100 \mu \mathrm{l})$ was then pipetted onto sheep blood agar (MAST, United Kingdom) prepared plates for the general culture of all bacteria and onto Listeria selective agar (MAST, United Kingdom) prepared plates for the selective culture of Listeria spp. and then spread evenly on the surface of the media. One (1) millilitre of the homogenate was pipetted onto the centre of chromogenic Compact Dry Escherichia colilColiform ready to use plates (Nissui Pharmaceuticals, Japan) for the selective culture of $E$. coli and other coliforms. All plates were incubated inverted at $37 \pm 2^{\circ} \mathrm{C}$ for $24 \pm 2$ hours. All samples showing positive growth for $E$. coli were then cultured on chromogenic CHROMagar 0157 (Life Technologies, France) prepared plates for the culture of $E$. coli $0157: \mathrm{H} 7$ by pipetting $50 \mu \mathrm{l}$ of sample onto the surface of the media, spreading and followed by incubation at $37 \pm 2{ }^{\circ} \mathrm{C}$ for $24 \pm 2$ hours.

The colony forming units based on the different colony morphological characteristics (colour, elevation, shape, structure, surface and type of haemolysis) observed on the different media were counted. Estimates of colony forming units per gram (cfu/g) were obtained using the formula:

$$
\mathrm{cfu} / \mathrm{g}=\frac{(\mathrm{cfu} \text { counted }) \times(\text { reciprocal of dilution factor })}{(\text { volume of homogenate plated } \mathrm{ml})}
$$

The morphologically different colony forming units were then picked using a sterile straight wire and sub-cultured onto sterile blood agar plates by streaking to isolate pure cultures of bacteria. The plates were incubated at $37 \pm 2{ }^{\circ} \mathrm{C}$ for 18 to 24 hours and the isolates obtained were used for the identification of bacteria. 


\section{Bacterial identification}

Bacterial identification was carried out in two steps; primary identification and then secondary identification. Primary identification included macroscopic examination of the colonies, the Gram stain for cellular morphology identification, and primary biochemical tests (catalase and oxidase tests). The Bergey's Manual of Determinative Bacteriology [29] was then followed to identify bacteria to the species level where possible.

Secondary identification was carried out using media that incorporates biochemical tests, namely MacConkey agar (MAST, United Kingdom), triple sugar iron agar (TSI), Simmon's citrate, urease, indole, sugar fermentation tests and analytical profiling index (API $20 \mathrm{NE}$ ) kits. These tests were carried out where appropriate following the Bergey's Manual of Determinative Bacteriology identification flow chart.

\section{Data summarization}

The different isolates of bacteria identified were grouped based on the primary biochemical test results. Two other groups; total E.coli and total coliforms, were used to assess the levels of faecal and environmental contamination of the different organs respectively. The prevalence of the different bacterial isolates identified in the different organs was then expressed as percentages. The mean abundance of the bacterial isolates on all the samples per organ was calculated as well as the standard error of the mean and counts of isolates were presented as the mean count plus/minus ( \pm ) standard error of the sample mean.

\section{Statistical Analysis}

The distribution of the data for all organs and isolates was tested for normality using the Shapiro-Wilk test and was observed to be not normally distributed at 0.05 level of significance. As a result, a non-parametric analysis of variance (ANOVA), Kruskal-Wallis test for completely randomized designs was used to test the distribution of each isolate in the different organs separately at 0.05 level of significance. Where there was significance difference in the omnibus ANOVA, multiple comparison tests were conducted using the Conover-Inman test with a Benjamin-Hochberg $(\mathrm{B}-\mathrm{H}) \mathrm{p}$-value adjustment [30, 31]. The B-H p-value adjustment method was used to control the false discovery rate (the expected proportion of significant results which are in fact false positive results). All statistical analysis and graphical presentations were carried out using R statistical software [32].

\section{RESULTS}

\section{Isolation and identification of bacteria}

A total of twelve (12) bacteria were isolated and seven (7) were identified to genus level, four (4) were identified to species level while one was identified to family level. There were five (5) notable groups to which these bacteria belonged based on the primary biochemical tests conducted. These were (i) Gram positive cocci-shaped catalase positive, (ii) Gram positive rod-shaped catalase positive, (iii) Gram negative cocci-shaped oxidase negative, (iv) Gram negative rod-shaped oxidase negative and (v) Gram negative rod-shaped oxidase positive bacteria (Table 1). The Gram negative rod-shaped oxidase negative (Enterobacteriaceae family) group was the most represented with six (6) members namely E.coli including E. coli 0157:H7 serotype, Citrobacter spp, Enterobacter spp, Klebsiella spp, Shigella spp. and Edwardsiella tarda.

Table-1: Different groups of bacteria with representative members identified in 0. niloticus in Lake Chivero (February, 2016).

\begin{tabular}{|l|l|l|}
\hline Group & Primary biochemical tests & Bacteria identified \\
\hline (i) & $\begin{array}{l}\text { Gram positive, cocci-shaped, } \\
\text { catalase positive }\end{array}$ & Staphylococcus spp. \\
\hline (ii) & $\begin{array}{l}\text { Gram positive, rod-shaped, } \\
\text { catalase positive }\end{array}$ & Bacillus subtilis, Listeria ivanovii and unidentified isolate. \\
\hline (iii) & $\begin{array}{l}\text { Gram negative, cocci- } \\
\text { shaped, oxidase negative }\end{array}$ & Acinetobacter spp. \\
\hline (iv) & $\begin{array}{l}\text { Gram negative, rod-shaped, } \\
\text { oxidase negative }\end{array}$ & $\begin{array}{l}\text { E.coli including E. coli O157:H7, Citrobacter spp, Enterobacter spp, } \\
\text { Klebsiella spp, Shigella spp. and Edwardsiella tarda. }\end{array}$ \\
\hline (v) & $\begin{array}{l}\text { Gram negative, rod-shaped, } \\
\text { oxidase positive }\end{array}$ & Aeromonas spp. \\
\hline
\end{tabular}

\section{Prevalence of bacteria}

The prevalence of bacterial isolated in the different organs is shown in Table 2 below. Staphylococcus spp. were most prevalent in primarily all organs ranging from $53 \%$ on liver to $100 \%$ on the skin while the E. coli $0157: H 7$ serotype was not isolated from the intestines, kidney and liver. 
Table-2: Prevalence ( $\%$ infected, $\mathrm{N}=30$ ) of the bacterial isolates on different organs of 0 . niloticus in Lake Chivero (February, 2016)

\begin{tabular}{|l|l|l|l|l|l|l|}
\hline Isolate & Skin & Gills & Muscle & Intestine & Liver & Kidney \\
\hline Acinetobacter spp. & 60.0 & 33.3 & 66.7 & 20.0 & 60.0 & 60.0 \\
\hline Aeromonas spp. & 6.7 & 33.3 & 13.3 & 20.0 & 33.3 & 26.7 \\
\hline B. subtilis & 26.7 & 20.0 & 6.7 & 66.7 & 46.7 & 53.3 \\
\hline Citrobacter spp. & 20.0 & 20.0 & 13.3 & 26.7 & 0.0 & 13.3 \\
\hline E. tarda & 6.7 & 26.7 & 40.0 & 33.3 & 20.0 & 26.7 \\
\hline Enterobacter spp. & 13.3 & 13.3 & 20.0 & 26.7 & 20.0 & 6.7 \\
\hline E. coli & 93.3 & 86.7 & 73.3 & 10.0 & 3.3 & 0.0 \\
\hline E. coli 0157:H7 & 13.3 & 16.7 & 6.7 & 0.0 & 0.0 & 0.0 \\
\hline L. ivanovii & 46.7 & 33.3 & 33.3 & 40.0 & 0.0 & 0.0 \\
\hline Klebsiella spp. & 13.3 & 0.0 & 20.0 & 33.3 & 46.7 & 40.0 \\
\hline Shigella spp. & 66.7 & 46.7 & 26.7 & 0.0 & 0.0 & 0.0 \\
\hline Staphylococcus spp. & 100.0 & 86.7 & 80.0 & 60.0 & 53.3 & 66.7 \\
\hline Unidentified & 100.0 & 80.0 & 86.7 & 6.7 & 0.0 & 26.7 \\
\hline
\end{tabular}

\section{Enumeration of bacteria}

The dominance in terms of grand means of the five groups indicated in Table 1 was as follows: group (iv) most dominant $\left(4.706 \times 10^{4} \mathrm{cfu} / \mathrm{g}\right)$, to group (iii), to group (i), to group (v) and to group (ii) least dominant $\left(5.183 \times 10^{3} \mathrm{cfu} / \mathrm{g}\right)$. The Enterobacteriaceae family (group iv) was subdivided further into the coliform group (Figure 2), namely E.coli, Citrobacter spp, Enterobacter spp, Klebsiella spp, and the non-coliform group namely Shigella spp. and Edwardsiella tarda. Coliforms were present on all organs, with highest total coliform counts on the skin $\left(2.778 \times 10^{4} \pm 3.848 \times 10^{3} \mathrm{cfu} / \mathrm{g}\right)$ and lowest on the liver $\left(1.398 \times 10^{2} \pm 2.384 \times 10^{1} \mathrm{cfu} / \mathrm{g}\right)$. Escherichia coli was present on all organs except the kidney, with highest counts on gills $\left(7.57 \times 10^{2} \pm 4.042 \times 10^{2} \mathrm{cfu} / \mathrm{g}\right)$ and lowest on liver $(4.333 \pm$ $6.022 \mathrm{cfu} / \mathrm{g})$.

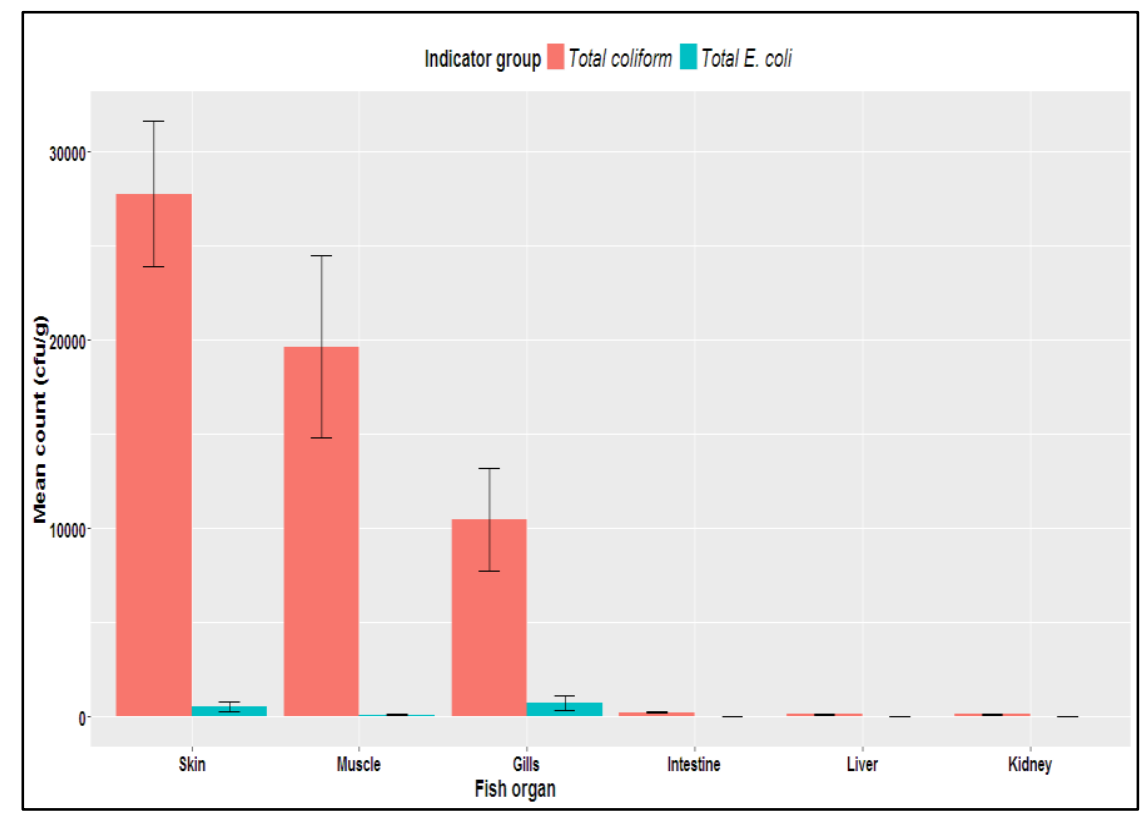

Fig-2: Mean E.coli and total coliform counts on different O. niloticus organs in Lake Chivero (February, 2016). Error bars represent the standard error of the sample mean

Staphylococcus spp. was isolated on all the organs and ranged from $8.03 \times 10^{2} \pm 2.403 \times 10^{2} \mathrm{cfu} / \mathrm{g}$ on the liver to $1.46 \times 10^{5}$ $\pm 4.014 \times 10^{4} \mathrm{cfu} / \mathrm{g}$ on the skin, while E. coli $0157: \mathrm{H} 7$ serotype was least abundant ranging from zero cfu/g on intestines, liver and kidney to $2.4 \times 10^{2} \pm 1.571 \times 10^{2} \mathrm{cfu} / \mathrm{g}$ on the skin (Figure 3).

\section{Diversity of bacterial mean abundance}

The diversity of bacteria isolated in this study varied between different organs as shown in Figure 3 below. The sum total of bacterial isolates ranged from $8.837 \times 10^{3} \mathrm{cfu} / \mathrm{g}$ on the kidney to $3.609 \times 10^{5} \mathrm{cfu} / \mathrm{g}$ on the skin and there was a significance difference $\left(p=2.2 \times 10^{-16}\right)$ of the mean abundances of isolates on all the organs. The skin and muscle had the greatest diversity of bacteria as they were infected with all the twelve isolates, while the kidney had the least diversity, not infected with E. coli, L. ivanovii and Shigella spp. 


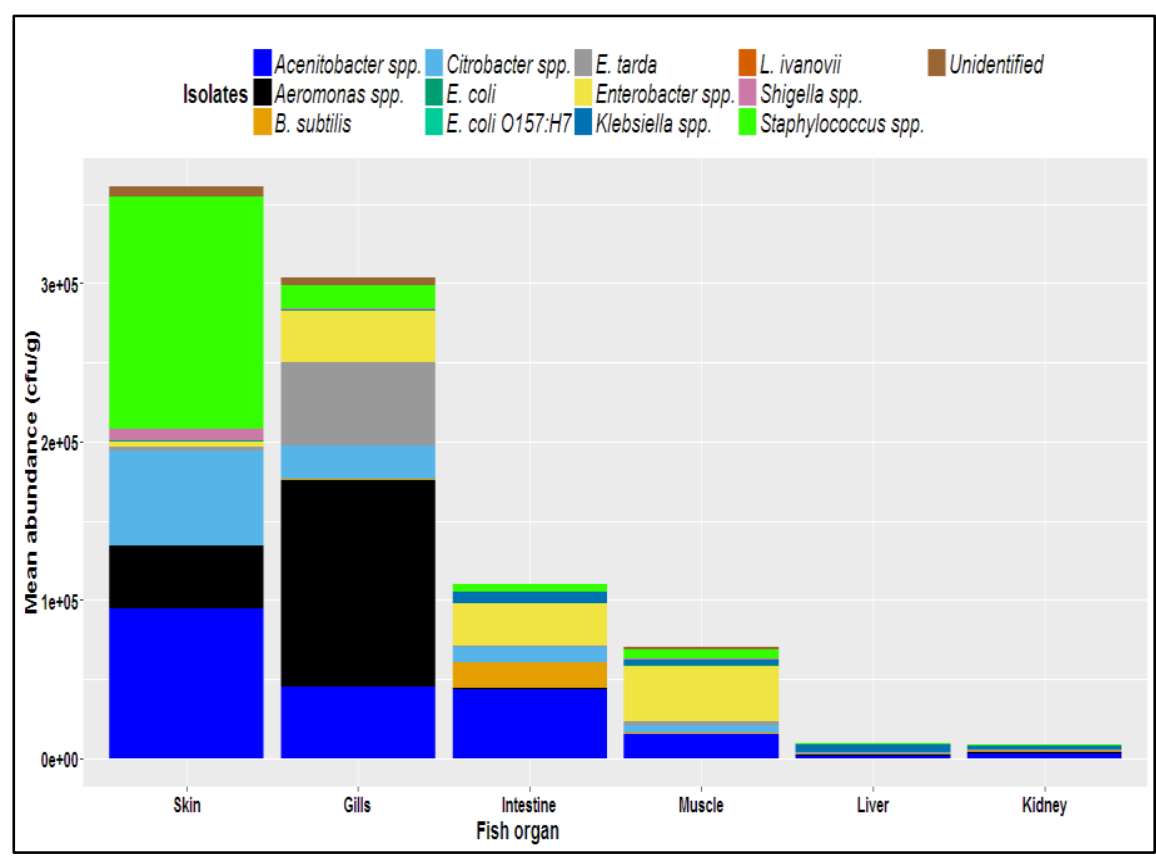

Fig-3: The bacterial diversity and abundance on the organs of 0 . niloticus in Lake Chivero (February, 2016)

A more specific analysis of the diversity and abundance of the bacterial isolates individually between the different organs is shown in Table 3 below. There was no significance difference $(p>0.05)$ in the mean abundance of Aeromonas spp, Citrobacter spp, E. tarda and Enterobacter spp. between the different organs. However, the mean abundances of these bacteria varied greatly. There were very high counts of Aeromonas spp. and E. tarda on the gills at $1.311 \times 10^{5} \pm 4.39 \times 10^{4} \mathrm{cfu} / \mathrm{g}$ and $5.298 \times 10^{4} \pm 2.8 \times 10^{4} \mathrm{cfu} / \mathrm{g}$ respectively, while low counts of these bacteria were recorded on the liver $\left(7.033 \times 10^{2} \pm 3.611 \times 10^{2} \mathrm{cfu} / \mathrm{g}\right)$ and kidney $\left(3.3 \times 10^{2} \pm\right.$ $1.238 \times 10^{2} \mathrm{cfu} / \mathrm{g}$ ) (Figure 3). Enterobacter spp. were very high on gills, intestine and muscle and lowest in the liver with counts of 3.23 $\times 10^{4} \pm 1.587 \times 10^{4} \mathrm{cfu} / \mathrm{g}, 2.725 \times 10^{4} \pm 1.567 \times 10^{4} \mathrm{cfu} / \mathrm{g}, 3.477 \times 10^{4} \pm 1.775 \times 10^{4} \mathrm{cfu} / \mathrm{g}$ and $1.167 \times 10^{2} \pm 4.868 \times 10^{1} \mathrm{cfu} / \mathrm{g}$ respectively. In addition, highest counts of Citrobacter spp. were recorded on the skin $\left(6.0 \times 10^{4} \pm 3.078 \times 10^{4} \mathrm{cfu} / \mathrm{g}\right)$ and not present on the liver.

Staphylococcus spp. had the greatest diversity and significance difference between the organs in which the skin had the greatest count followed by the gills and finally the kidney and liver (Table 3). The skin was in most cases the highly infected organ and was dominated by Acinetobacter spp., Aeromonas spp., Citrobacter spp., Staphylococcus spp. and the unidentified isolate. It was noted that internal organs namely, intestines, kidney and liver were least infected with bacteria except for the highest counts of $B$. subtilis on the intestines and of Klebsiella spp. on intestines, liver and kidney (Figure 3). The infection of the muscle with bacterial isolates was intermediate in most cases in relation to other organs (Table 3).

Table-3: Kruskal-Wallis test ( $p$-value) for the isolates mean abundance variation between different organs of 0 . niloticus in Lake Chivero (February, 2016) and Conover-Inman multiple comparison tests with B-H p-value adjustment

\begin{tabular}{|l|l|l|}
\hline Bacterial isolate & Kruskal-Wallis test & $\begin{array}{l}\text { Conover-Inman test (Organs with significance difference } \\
\text { of isolate) }\end{array}$ \\
\hline Acinetobacter spp. & $5.44 \times 10^{-4}$ & $\mathrm{~S}>\mathrm{G}>\mathrm{I}>\mathrm{M}>\mathrm{K}>\mathrm{L}$ \\
\hline Aeromonas spp. & $5.508 \times 10^{-2}$ & - \\
\hline B. subtilis & $2.34 \times 10^{-5}$ & $\mathrm{I}>\mathrm{M}>\mathrm{G}>\mathrm{K}>\mathrm{S}>\mathrm{L}$ \\
\hline Citrobacter spp. & $8.733 \times 10^{-2}$ & - \\
\hline E. tarda & $7.493 \times 10^{-2}$ & - \\
\hline Enterobacter spp. & $3.486 \times 10^{-1}$ & - \\
\hline E. coli & $2.20 \times 10^{-16}$ & $\mathrm{G}>\mathrm{S}>\mathrm{M}>\mathrm{I}>\mathrm{L}>\mathrm{K}$ \\
\hline E. coli O157: H7 & $1.32 \times 10^{-2}$ & $\mathrm{~S}>\mathrm{G}>\mathrm{M}>\mathrm{I}, \mathrm{K}, \mathrm{L}$ \\
\hline L. ivanovii & $2.95 \times 10^{-6}$ & $\mathrm{~S}>\mathrm{I}>\mathrm{G}, \mathrm{M}>\mathrm{K}, \mathrm{L}$ \\
\hline Klebsiella spp. & $5.09 \times 10^{-4}$ & $\mathrm{I}>\mathrm{L}>\mathrm{M}>\mathrm{K}>\mathrm{S}>\mathrm{G}$ \\
\hline Shigella spp. & $1.84 \times 10^{-13}$ & $\mathrm{~S}>\mathrm{M}>\mathrm{G}>\mathrm{I}, \mathrm{K}, \mathrm{L}$ \\
\hline Staphylococcus spp. & $2.20 \times 10^{-16}$ & $\mathrm{~S}>\mathrm{G}>\mathrm{M}>\mathrm{I}>\mathrm{K}>\mathrm{L}$ \\
\hline Unidentified & $2.20 \times 10^{-16}$ & $\mathrm{~S}>\mathrm{G}>\mathrm{M}>\mathrm{K}>\mathrm{I}>\mathrm{L}$ \\
\hline
\end{tabular}

$\mathrm{G}=$ gills, $\mathrm{I}=$ intestine, $\mathrm{K}=$ kidney, $\mathrm{L}=$ liver, $\mathrm{M}=$ muscle and $\mathrm{S}=$ skin. 


\section{Discussion}

In this study it was noted that the most prevalent bacteria were not the most abundant except for the Staphylococcus spp. On the skin Staphylococcus spp. was most prevalent and also most abundant ( $\left.1.46 \times 10^{5} \pm 4.014 \times 10^{4} \mathrm{cfu} / \mathrm{g}\right)$. On the gills, E. coli was most prevalent but Aeromonas spp. were most abundant $\left(1.311 \times 10^{5} \pm 4.39 \times 10^{4} \mathrm{cfu} / \mathrm{g}\right)$ while the intestines were dominated by Acinetobacter spp. $\left(4.379 \times 10^{4} \pm 2.749 \times 10^{4} \mathrm{cfu} / \mathrm{g}\right)$ although $B$. subtilis was most prevalent. The kidney was also dominated by Acinetobacter spp. (3.057 × $\left.10^{3} \pm 9.904 \times 10^{2} \mathrm{cfu} / \mathrm{g}\right)$ and Staphylococcus spp. were most prevalent, while in the liver Acinetobacter spp. were most prevalent and Klebsiella spp. were most abundant $\left(5.06 \times 10^{3} \pm 2.358 \times 10^{3} \mathrm{cfu} / \mathrm{g}\right)$.

The most represented group of bacteria in this study was the Enterobacteriaceae family owing to its wide distribution in the environment including the soil, water and plants as well as in humans and animals alimentary canals [33]. Six (6) members of this family were associated with 0 . niloticus in Lake Chivero of which Enterobacter spp. were predominant $\left(1.644 \times 10^{4} \mathrm{cfu} / \mathrm{g}\right) \mathrm{and} E$. coli 0157:H7 was least dominant $\left(5.444 \times 10^{1}\right.$

$\mathrm{cfu} / \mathrm{g})$. The bacteria were isolated from all organs of the fish tested in this study and this was consistent with study by Hassan et al. [34], in which Citrobacter spp., E. coli, Enterobacter spp., Klebsiella spp., Proteus spp. and Salmonella spp. were identified on the gills, intestine, liver and kidney. Although the Enterobacteriaceae family was most represented group, Acinetobacter spp. and Staphylococcus spp. were most abundant and similar results were reported by Alyl et al. [35].

Members of the Enterobacteriaceae family, namely Citrobacter spp., E. coli, Enterobacter spp., Klebsiella spp. and Salmonella spp., are generally harmless to fish and can be considered part of the bacterial flora of fish especially in eutrophic environments. However, the bacteria were reported to cause increased mortalities of 0 . niloticus of up to $43.3 \%$ caused by Enterobacter cloacae though no clinical signs of infection were observed on the fish organs [36]. In this study the skin showed signs of infection namely reddening on the ventral surfaces of the fish (Figure 4).

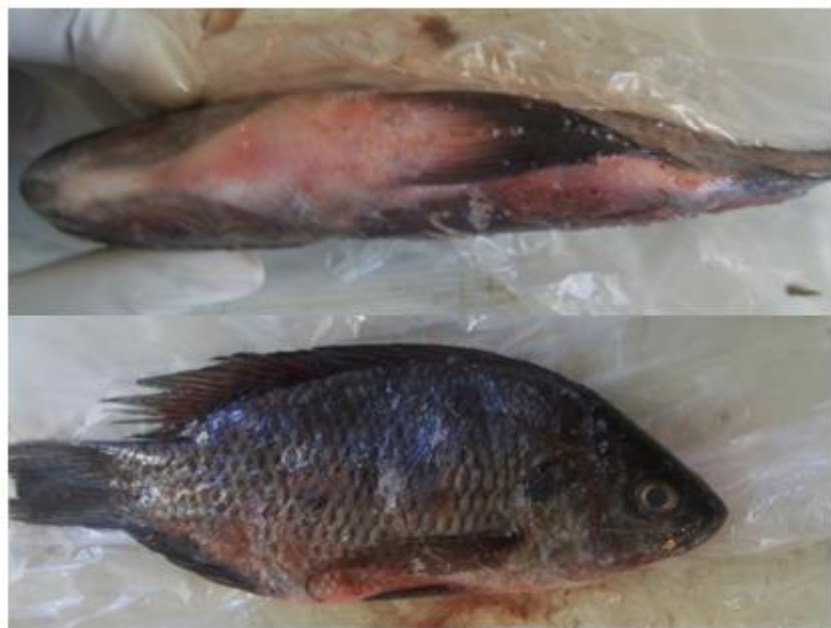

Fig-4: Reddening of skin on the ventral surface of 0 . niloticus in Lake Chivero (February, 2016)

Escherichia coli and other coliforms were present on fish samples tested. The presence of E.coli and a count of not less than $10^{1} \mathrm{cfu} / \mathrm{g}$ coliforms do not conform with the standards stipulated by the CODEX Alimentarius [37] and the Zimbabwe food standards regulations [38]. Although $E$. coli is part of the normal flora of humans and is harmless, certain strains of the bacterium are pathogenic and are responsible for gastrointestinal illnesses. The presence of $E$. coli and other coliforms in high numbers on the skin, gills and muscle organs of the fish (Figure 2) indicated that these organs are the most likely contaminated or infected with bacteria in the environment (water contaminated with sewage and industrial effluent). The presence of $E$. coli and other coliforms is not directly harmful but is a presumptive indication of faecal contamination and that other pathogenic bacteria especially enteric ones may be present $[17,39]$.

Escherichia coli was highly prevalent (greater than $70 \%$ ) and abundant (greater than $10^{1} \mathrm{cfu} / \mathrm{g}$ ) on the skin, muscle and gills of $O$. niloticus deeming the fish unfit for human consumption. Furthermore, human pathogenic $E$. coli, namely E. coli $0157: \mathrm{H} 7$ (an enterohaemorrhagic serotype) was isolated on the skin, muscle and gills increasing the risk of disease outbreak in consumers. In 2006, E. coli 0157:H7 caused a diarrheal outbreak that resulted in over 205 illnesses and 3 deaths in the United States of America [40]. Other strains of $E$. coli such as enterotoxigenic, enteroinvasive, vero-cytotoxin producing and enteroaggregative $0104: \mathrm{H} 4$ have been the cause of fatal diarrheal illnesses such as the 2011 E. coli 0104:H4 outbreak that claimed 48 lives with 857 haemolyticuremic syndrome reported cases in Germany [41]. Other human pathogenic bacteria were also present, namely L. ivanovii, Shigella spp and Staphylococcus spp., and E. tarda is an opportunistic pathogen causing gastrointestinal illnesses [33]. Gastrointestinal 
illnesses (nausea, vomiting, diarrhoea and abdominal pain) resulting from consuming contaminated food products are alarming causes of concern globally. Though the symptoms are usually mild and only lasting a few days and a small proportion is reported, over a million cases are reported annually resulting in thousands of deaths [42].

The external organs of 0 . niloticus had the highest load of bacteria (Figure 3 ) and this can be explained by the fact that these organs are constantly in contact with the environment which results in increased contamination and infection with bacteria. The skin was infected with all bacteria isolated and had the highest bacterial load. The underlying muscle tissue was also infected with all bacterial isolates though the bacterial count was lower than that of the gills and the skin. This suggests that bacteria present in the environment will infect the skin and end up in the muscle. The reduced counts of bacteria on the muscle are similar to the study by Mandal et al. [43]. One of the causes of the reduction of bacterial load in the internal organs mainly muscle, intestine, liver and kidney of $O$. niloticus is the up-regulation of genes encoding the expression of viperin, an anti-viral and anti-bacterial protein [44]. This was indicated by the reduction in prevalence and abundance of bacterial isolates from the skin to the kidney (Table 2, Figure 3). In this study, fish pathogenic bacteria were identified. Edwardsiella tarda is the major pathogen of 0 . niloticus causing edwardsiella septicaemia [27, 45]. It causes swelling of the abdomen due to ascites and haemorrhages on the body wall [46]. Aeromonas spp. are responsible for haemorrhagic septicaemia including reddening of the body wall and haemorrhages in the viscera and peritoneum [47, 48]. Some of the fish sampled in this study showed these symptoms (Figure 4). Some of the bacteria isolated in the present study have been listed as emerging opportunistic pathogens of fish [49] causing mortalities of up to $20 \%$ in trout and carp, and are well known for transmitting antibiotic resistance genes $[50,51]$.

The presence of large numbers of bacteria in freshly caught fish in the lake is a cause of concern. The concentration of bacteria increases to high levels that pose danger to consumers when improper handling and storage is practised [10]. At high concentrations, bacteria produce toxins that can lead to consumer illness. The major microorganisms involved are Staphylococcus aureus and Clostrodium botulinum [52]. Staphylococcus spp. were the most dominant and prevalent microorganism on the skin and muscle in this study and could result in diseases such as neonatal meningitis and mastitis in humans [51]. These bacteria give evidence that the lake is heavily polluted by sewage effluent among other pollutants. A few years ago the Harare City Council banned the consumption of Lake Chivero fish due to an outbreak of typhoid fever in Harare and other areas [53].

The diversity of fish pathogens (Aeromonas spp. and E. tarda) were found to be more prevalent on internal organs whereas opportunistic pathogens were highly prevalent on most organs (Table 2). This suggests that 0 . niloticus is at risk of disease from these bacteria. Members of the Enterobacteriaceae family and human pathogenic bacteria are more prevalent and significantly abundant on the skin and muscle, organs that are handled and consumed, increasing the risk of disease outbreak in consumers. Oreochromis niloticus in Lake Chivero is thus a potential source of cross contamination of other food products especially those consumed uncooked from which many food poisoning cases are reported [10].

Streptococcus spp. has been identified in Lake Chivero water [23]. However, none of the fish sampled in this study were infected with Streptococcus spp. This bacterium is one of the etiological agents of bacterial kidney disease together with Renibacterium salmoninarum in Nile tilapia [10]. Kidney infection with Streptococcus iniae can results in devastating mortalities of fish $[54]$.

Lake Chivero is infested by aquatic parasites [23] which are prevalent on fish [19]. The presence of parasites can result in concurrent infection of fish with parasites and bacteria. A study has shown that concurrent infection of fish with Gyrodactylus niloticus and S. iniae results in 0 . niloticus mortalities of greater than $40 \%$ in contrast to $7 \%$ and $0 \%$ due to S. iniae and G. niloticus alone respectively [55]. In the same study the parasite was shown to harbour viable bacteria after several cycles of infection suggesting that the parasite was a potential mechanical vector of the bacterium. This can also be the case in Lake Chivero where both parasites and bacteria are prevalent which could result in increased concurrent infections and mortalities.

In the current study there were some important limitations. Anaerobic bacteria could not be identified due to the specialized equipment required for sample collection, namely sterile air-free containers and anaerobic transport medium [33]. Thus, in this study the bacterial flora described includes aerobic and facultative aerobic bacteria only, although obligate anaerobic bacteria such as Clostrodium spp. and Eubacterium spp. are also associated with fish [9]. A culture-based technique was used in this study and it has disadvantages which mainly include out-competition of slow growing microorganisms by fast-growing ones and the failure to identify unculturable microorganisms [46]. Several microorganisms are extremely fastidious and require specialized supplemented media for growth in the laboratory [56]. In the current study only one such bacterium, L. ivanovii, was cultured on listeria selective media.

\section{CONCLUSIONS}

The abundance and diversity of bacteria varied between different organs and this indicates stressful environmental conditions that may negatively impact the populations of 0 . niloticus in the lake. The results indicated 0 . niloticus to be heavily infected with bacteria some of which are known to be pathogenic to fish and others pathogenic to humans. The fish therefore do not satisfy the food safety standards stipulated by the CODEX Alimentarius and are deemed unfit for consumption. Individuals who consume fish from Lake Chivero are therefore at risk of illness especially children, the elderly and immunocompromised individuals. 
Consumers that intend to eat the fish should be certain that the fish are thoroughly cooked to reach an internal temperature of $100{ }^{\circ} \mathrm{C}$ for a minute [52]. Though disease outbreak is self-limiting, people that consume fish from Lake Chivero are at a greater risk of suffering from infections due to exposure to the different pathogens isolated.

\section{Additional Points \\ RECOMMENDATIONS}

Measures should be put in place to remove water hyacinth plants in Lake Chivero and invest in sewage treatment in order to reduce the nutrient load in the lake which may indirectly increase the environmental stress for the fish and more likely to cause fish to suffer from various bacterial diseases. Certain forms of Staphylococcus spp. have high antibiotic resistance, antimicrobial susceptibility tests of bacteria associated with 0 . niloticus in Lake Chivero should thus be carried out to ascertain the danger that may be encountered during treatment of humans [57].

Molecular-based techniques including polymerase chain reaction, 16S rRNA and reverse transcriptase sequencing should be employed to carry out the molecular systematics of bacteria associated with the fish [58]. This will enable identification of all bacterial groups including unculturable ones as well as avoid the challenges that may be encountered when culturing anaerobic bacteria. However, culture-based methods may still give valid results provided several different media that target different genera of bacteria are used [59]. These genera include bacteria such as Salmonella spp., Vibrio spp., and Campylobacter spp. which are often associated with fish [10] and fish pathogenic bacteria such as Flavobacterium spp. and Flexibacter spp. that require cytophaga agar to be cultured [27].

\section{Data Availability}

The data used to support the findings and conclusions of this study are available from the corresponding author upon request.

\section{Conflicts of Interest}

The authors declare that there are no conflicts of interest regarding this publication.

\section{REFERENCES}

1. Okafor, N. (2010). Environmental Microbiology of Aquatic and Waste Systems, Springer Scientific, USA.

2. Austin, B. (2006). The Bacterial Microflora of Fish, Revised, The Scientific World Journal, 6: 931-945.

3. Kashiwada, K., Tejima, S., \& Kanazama, A. (1970). Evidence of the production of vitamin B12 by microorganisms in the intestine of carp, Bulletin of the Japanese Society for the Science of Fish, 36: 421 - 434.

4. Baron, S., Granier, S. A., Larvor, E., Jouy, E., Cineux, M., Wilhelm, A., \& Chauvin, C. (2017). Aeromonas diversity and antimicrobial susceptibility in freshwater-an attempt to set generic epidemiological cut-off values. Frontiers in microbiology, 8 , 503.

5. Achenbach, L. A., Carey, J., \& Madigan, M. T. (2001). Photosynthetic and phylogenetic primer for detection of anoxygenic photographs in natural environments, Applied and Environmental Microbiology, 67:2922-2926.

6. Austin, B. (2002). The bacterial flora of fish, The Scientific World Journal, 2:558-572.

7. Emikpe, B. O., Adebisi, T., \& Adedeji, O. B. (2011). Bacteria load on the skin and stomach of Clarias gariepinus and Oreochromis niloticus from Ibadam, South West Nigeria: Public Health Implications, Journal of Microbiology and Biotechnology Research, 1(1): $52-59$.

8. Ibrahim, B. U., Baba, J., \& Sheshi, M. S. (2014). Isolation and identification of bacteria associated with fresh and smoked fish (Clarias gariepinus) in Minna Metropolis, Niger State. Nigeria, Journal of Applied and Environmental Microbiology, 2(3): 81 - 85.

9. Austin, B., \& Austin, D. (2007). The bacterial diseases of fish (4th edition.), Praxis Publishing, Springer, UK.

10. Novotny, L., Dvorska, L., Lorencova, A., Beran, V., \& Paalvik, I. (2004). Fish: a potential source of bacterial pathogens for human beings. Veterinary Medicine, 49(9):343-58.

11. Lio-Po, G. D., \& Lim, L. S. (2014). Infectious diseases of warmwater fish in fresh water. Diseases and disorders of finfish in cage culture. 2nd edition. Wallingford and. Boston: CAB International, 193-253.

12. Meyers, T., Burton, T., Bentz, C., \& Starkey, N. (2008). Common diseases of wild and cultured fishes in Alaska. Fish Pathology Laboratories, Alaska Department of Fish and Game. Anchorage, Alaska.

13. Magadza, C. H. D. (1997). Water pollution and catchment management in Lake Chivero. In: Moyo, N. A. G., Editor. Lake Chivero: a Polluted Lake. University of Zimbabwe Publications, Harare, Zimbabwe: 13-26.

14. Moyo, N. and Mtetwa, S. (2002). Water quality management and pollution control. In: Hirji, R., Johnson, P., Maro, P., \& Chiuta, M. T., Editors. Defining Mainstream and environmental Sustainability in Water Resources Management in Southern Africa, SADC/IUCN/SARPC/World Bank, Maseru/Harare/Washington.

15. Magadza, C. H. D. (2003). Lake Chivero: A Management Case Study, Lakes and Reservoirs Research and Management, 8: 69 91.

16. Marti, E., Variatza, E., \& Balcazar, J. L. (2014). The role of aquatic ecosystems as reservoirs of antibiotic resistance, Trends in Microbiology, 22:36-41. 
17. Rizzo, L., Manaia, C., Merlin, C., Schwartz, T., Dagot, C., Ploy, M. C., ... \& Fatta-Kassinos, D. (2013). Urban wastewater treatment plants as hotspots for antibiotic resistant bacteria and genes spread into the environment: a review. Science of the total environment, 447, 345-360.

18. Chifamba, P. C. (1998). Status of Oreochromis niloticus in Lake Kariba, Zimbabwe, following escape from fish farms. In: Cowx, I. G., Editor. Stocking and introduction of fish, Oxford, UK: Fishing News Books: 267-273.

19. Barson, M. (2004). The occurrence of Contracaecum sp. larvae (Nematoda: Anisakidae) in the catfish Clarias gariepinus (Burchell) from Lake Chivero, Zimbabwe. Onderstepoort Journal of Veterinary Research, 71(1), 35-39.

20. Ndebele, M. R., \& Magadza, C. H. (2006). The occurrence of microcystin-LR in Lake Chivero, Zimbabwe. Lakes \& Reservoirs: Research \& Management, 11(1), 57-62.

21. Minshall, J. E. (1978). A preliminary investigation of the Sarotherodan marochir (Boelenger) on a shallow shoreline in Lake Mcllwaine, Rhodesia, MSc Thesis, University of Rhodesia.

22. Mhlanga, L., Day, J., Chimbari, M., Siziba, N., \& Cronberg, G. (2006). Observations on limnological conditions associated with a fish kill of Oreochromis niloticus in Lake Chivero following collapse of an algal bloom. African Journal of Ecology, 44(2), $199-208$.

23. Dalu, T., Barson, M., \& Nhiwatiwa, T. (2011). Impact of intestinal microorganisms and protozoan parasites on drinking water quality in Harare, Zimbabwe. Journal of Water, Sanitation and Hygiene for Development, 1(3), 153-163.

24. Zengeya, T. A., \& Marshall, B. E. (2007). Trophic interrelationships amongst cichlid fishes in a tropical African reservoir (Lake Chivero, Zimbabwe). Hydrobiologia, 592(1), 175-182.

25. Food and Agricultural Organization (FAO). (2007). Social issues in small-scale fisheries: How a human rights perspective can contribute to respective fisheries. Presentation to FAO Committee of Fisheries No 27. Rome, Italy.

26. Utete, B., \& Chikova, E. H. (2013). Gonadal state and condition factor of Oreochromis niloticus (Linnaeus 1758) in a hypereutrophic lake. Journal of Water Resources and Ocean Science, 2(6), 165-169.

27. Inglis, V., Roberts, R. J., \& Bromage, N. P. (1993). Bacterial diseases of fish, Black Scientific publications, London.

28. Burke, N.A., \& Thornton, J.A. (1982). The creation of Lake Mcllwaine: History and design. In: Thornton, J. A. and Nduku, W. K., Editors. Lake Mcllwaine: The Eutrophication and Recovery of a Tropical Man-made Lake. Dr. W. Junk Publishers, The Hague. Netherlands.

29. Holt, J.G., Krieg, N.R., Sneath, P.H.A., \& Williams, S.T. (1994). Bergey's manual of determinative bacteriology (9th edition), Williams and Wilkins, Baltimore.

30. Conover, W. J., \& Iman, R. L. (1979). On multiple-comparisons procedures. Technical Report LA-7677-MS, Los Alamos Scientific Laboratory.

31. Benjamini, Y., \& Hochberg, Y. (1995). Controlling the false discovery rate: a practical and powerful approach to multiple testing, Journal of the Royal Statistical Society Series B 57: 289-300.

32. R Core Team. (2016). R: A language and environment for statistical computing. R Foundation for Statistical Computing, Vienna, Austria, https://www.R-project.org/. Accessed 31 March 2016.

33. Markey B. K., Leonard F. C., Archambault M., Cullinane A., \& Maguire D. (2013). Clinical Veterinary Microbiology (2nd ed.), Elsevier, NY.

34. Hassan, A. H. M., Noor El Deen, A. E., Galal, H. M., Dorgham, S. M., Bakry, M. A., \& Hakim, A. S. (2012). Further Characterization of Enterobacteriaceae Isolated from Cultured Freshwater Fish in Kafr El Shiek Governorate: Clinical, Biochemical and Histopathological Study with Emphasis on Treatment Trials, Global Veterinaria, 9(5): 617-629.

35. Marcel, G., Sabri, M. Y., Siti-Zahrah, A., \& Emikpe, B. O. (2013). Water condition and identification of potential pathogenic bacteria from red tilapia reared in cage-cultured system in two different water bodies in Malaysia, African Journal of Microbiology Research, 7(47): 5330-5337.

36. Aly, S. M., Nouh, W. G., \& Salem-Bekhit, M. M. (2012). Bacteriological and Histopathological Studies on Enterobacteriacea in Nile Tilapia Oreochromis Niloticus. Journal of Pharmaceutical andBiomedical Sciences, 2(7), 94-104.

37. Food and Agricultural Organization (FAO). (1993). Manual of food quality control: Imported food inspection, FAO Food and Nutrition paper, 14(15), Rome.

38. Ministry of Health and Child Care. (2015). Food and Food Standards (Import and Export) regulations: Statutory Instrument 8 of 2015, http://www.cfuzim.org/index.php/legal-the-law/5053-statutory-instrument-8-of-2015-food-and-food-standards-import-andexport-regulations-2015, Accessed 17 April 2016.

39. Cheesbrough, M. (2006). District Laboratory Practice in Tropical Countries (2nd edition), Cambridge University Press, NY.

40. Centers for Disease Control and Prevention (CDC). (2006). E. coli Outbreak - Update, CDC Foodborne and Diarrheal Diseases Branch, USA.

41. World Health Organization, (WHO). (2011). EHEC outbreak, https://web.archive.org/web/20110612212804/http://www.gaertnerhof.org/, Accessed 22 April 2016.

42. World Health Organization, WHO. (2003). Water Quality: Guidelines, standards and health. Guidelines for Drinking water quality, IWA publishing, London.

43. Mandal, S. C., Hasan, M., Rahman, M. S., Manik, M. H., Mahmud, Z. H. and Islam, S. (2009). Coliform Bacteria in Nile Tilapia, Oreochromis niloticus of Shrimp-Gher, Pond and Fish Market, World Journal of Fish and Marine Sciences, 1(3): 160-166.

44. Lee, S. H., Peng, K. C., Lee, L. H., Pan, C. Y., Hour, A. L., Her, G. M., ... \& Chen, J. Y. (2013). Characterization of tilapia (Oreochromis niloticus) viperin expression, and inhibition of bacterial growth and modulation of immune-related gene expression by electrotransfer of viperin DNA into zebrafish muscle. Veterinary immunology and immunopathology, 151(3-4), $217-228$. 
45. Austin, B. (2015). Aeromonas fish pathogens. In: Graf, J., Editor. Aeromonas, Storrs, CT: Caister Academic Press, 45-65.

46. Nakatsugawa, T. (1983). Edwardsiella tarda isolated from cultured young flounder, Fish Pathology, 18(2):99-101.

47. Figueras, M. J., and Baez-Higalgo, R. (2015). Aeromonas infections in humans. In: Graf, J., Editor. Aeromonas, Storrs, CT: Caister Academic Press, 67-107.

48. Petty, B. D., \& Francis-Floyd, R. (2015). Bacterial diseases of fish, http://www.merckvetmanual.com/mvm/exotic_and_laboratory_animals/aquarium_fishes/bacterial_diseases_of_fish.html, Accessed 20 April 2016.

49. Kozińska, A., Paździor, E., Pękala, A., \& Niemczuk, W. (2014). Acinetobacter johnsonii and Acinetobacter lwoffii - the emerging fish pathogens, Bulletin of the Veterinary Institute in Pulawy, 58:193-199.

50. Smith, P., Alday-Sanz, V., Matysczak, J., Moulin, G., Lavilla-Pitogo, C. R., and Prater, D. (2013). Monitoring and surveillance of antimicrobial resistance in microorganisms associated with aquatic animals. OIE Scientific and Technical Review, 32:583-593.

51. Walakira, J., Akoll, P., Engole, M., Sserwadda, M., Nkambo, M., Namulawa, V., Kityo, G., Musimbo, F., Abaho, I., Kasigwa, H., Mbabazi, D., Kahwa, G., Naigaga, I., Birungi, D., Rutaisire, J., \& Majalija, S. (2014). Common fish diseases and parasites affecting wild and farmed Tilapia and catfish in Central and Western Uganda, Uganda Journal of Agricultural Sciences, 15(2): 113-125.

52. Food and Drug Administartion (FDA). (2011). Fish and Fishery Products: Hazards and Controls Guidance (4th ed.), http://www.fda.gov/FoodGuidances, Accessed 21 April 2016.

53. Zimbabwe Broadcasting Corporation (ZBC), 6 February 2012. Lake Chivero fish face ban, www.zbc.co.zw/index, Accessed 26 February 2015.

54. Roberts, R. J. (1989). Fish Pathology (2nd edition), Bailliere Tindall, London. Controls Guidance (4th ed.), http://www.fda.gov/FoodGuidances, Accessed 21 April 2016

55. Shoemaker, C.A., Xu, D., Klesius, P.H., \& Evans, J.J. (2008). Concurrent infections (parasitism and bacterial diesease) in tilapia, Proceedings of the 8th International Symposium on Talipia in Aquaculture. Cairo, Egypt, 2:1365-1375.

56. World organization for animal health (OIE) (2014). OIE terrestrial manual: Listeria monocytogenes, www.ioe.int, Accessed 20 April 2016.

57. Wamala, S. P., Mugimba, K. K., Mutoloki, J., Evensen, Ø., Mdegela, R., Byarugaba, D. K., \& Sorum, H. (2018). Occurrence and antibiotic susceptibility of fish bacteria isolated from Oreochromis niloticus (Nile tilapia) and Clarias gariepinus (African catfish) in Uganda, Fisheries and Aquatic Sciences, 21:6.

58. Shin, H. B., Yoon, J., Lee, Y., Kim, M. S., \& Lee, K. (2015). Comparison of maldi-tof ms, housekeeping gene sequencing, and 16s r RNA gene sequencing for identification of Aeromonas clinical isolates, Yonsei Medical Journal, 56: 550-555.

59. Boari, C. A., Pereira, G. I., Valeriano, C., Silva, B. C., Mendes de Morais, V., Figueiredo, H. C. P., \& Piccoli, R. H. (2008). Bacterial ecology of tilapia fresh fillets and some factors that can influence their microbial quality, Ciência e Tecnologia de Alimentos, 28(4): 863-867. 